\title{
Essential Oils in the Diet of Crossbred ( $1 / 2$ Angus vs. $1 / 2$ Nellore) Bulls Finished in Feedlot on Animal Performance, Feed Efficiency and Carcass Characteristics
}

\author{
Dayane Cristina Rivaroli ${ }^{1}$, Rodolpho Martin do Prado ${ }^{1}$, Mariana Garcia Ornaghi ${ }^{1}$, Camila Mottin ${ }^{1}$, \\ Tatiane Rogério Ramos ${ }^{1}$, Ana Guerrero Barrado ${ }^{1,2}$, André Mendes Jorge ${ }^{3} \&$ Ivanor Nunes do Prado ${ }^{1}$ \\ ${ }^{1}$ Department of Animal Science, State University of Maringá, Maringá, Brazil \\ ${ }^{2}$ Department of Animal Production and Food Science, Instituto Agroalimentario de Aragón-IA2 (Universidad de \\ Zaragoza-CITA), Zaragoza, Spain \\ ${ }^{3}$ Department of Animal Production, São Paulo State University, Botucatu, Brazil \\ Correspondence: Ivanor Nunes do Prado, Department of Animal Science, State University of Maringá, Av. \\ Colombo, 5790, 87020-900, Maringá, Brazil. Tel: 55-44-3011-8931. Fax: 55-3011-8977. E-mail: \\ inprado@uem.br
}

Received: April 30, 2017

doi:10.5539/jas.v9n10p205
Accepted: August 24, $2017 \quad$ Online Published: September 15, 2017

URL: https://doi.org/10.5539/jas.v9n10p205

\begin{abstract}
This experiment was carried out to evaluate the animal performance, feed efficiency and carcass characteristics of 27 crossbred bulls ( $1 / 2$ Angus vs. $1 / 2$ Nellore), finished in feedlot for 120 days, with the addition of distinct levels of essential oils in the diets. The experiment was conducted in a completely randomized trial and animals were distributed into three treatments: control $(\mathrm{CON})$, addition of $500 \mathrm{mg} / \mathrm{kg}$ of DM/animal/day of a mix of essential oils (E500), and addition of $1000 \mathrm{mg} / \mathrm{kg}$ of DM/animal/day of a mix of essential oils (E1000). The essential oils supplemented to the diets were based on a combination of vegetal extracts from: oregano, garlic, lemon, rosemary, thymus, eucalyptus and sweet orange. The bulls had an average age of $12 \pm 2$ months and weight of $243.4 \pm 6.8 \mathrm{~kg}$ when the trial started. The roughage and concentrate ratio was $10 \%$ and $90 \%$, respectively. The inclusion of essentials oils in the diets did not affect final body weight, average daily gain, and feed intake, but there was a tendency for improved feed efficiency for the E500 treatment. The ADG ranged from 1.55 to 1.70 . Average DMI and feed conversion were $7.07 \mathrm{~kg} /$ day and 4.31, respectively. Essentials oil levels did not affect the carcass characteristics. More studies are needed to elucidate the synergism of combinations of essential oils in the rumen.
\end{abstract}

Keywords: cattle, meat quality, natural additives, probiotics, plant extract

\section{Introduction}

Brazilian beef production is characterized by the use of grazing systems $(90 \%)$, zebu animals and their crosses $(80 \%)$, increased slaughter age (48 months) and low weight gain throughout life $(0.60 \mathrm{~kg} /$ day $)$ (Ferraz \& Felício, 2010). The use of feedlot, which is based on diets with high levels of grains and cereals, is a tool to improve production efficiency (e.g. reduced slaughter age and increased weight gain) and meat quality (Prado et al., 2008). However, feeding management malpractices for ruminants, such as intake of substations amounts of grains, can result in a drastic drop of rumen $\mathrm{pH}$, usually ensuing a metabolic disorder known as acute acidosis (Owens et al., 1998). Thus, ionophores can be added into the diets of cattle to modulate rumen fermentation and buffer the rumen, and the outcome can be improved performance and feed efficiency (Russell \& Strobel, 1989). However, the use of antibiotics is facing social criticism due to presence of residues in meat, and the proliferation and transmission of resistant bacteria via the food chain (OJEU, 2003; Russell \& Houlihan, 2003). Hence, new alternatives to be used as rumen modulators are in need to cope with the increasing demand for production and safety of livestock products.

Natural products, such as plant extracts and essential oils, are receiving increased attention to be used to improve livestock production. Essential oils are complex mixtures of secondary plant metabolites that can be obtained from plant parts (flowers, buds, seeds, leaves, twigs, barks, fruits, and roots) and they are associated with plant characteristic essences and fragrances (Burt, 2004). Essential oils have long been used in the pharmaceutical and 
cosmetic industry (Greathead, 2003). These products have some advantages over commonly used antibiotics, since they can be residue-free and are mostly safe for the food industry (Benchaar et al., 2008).

Active compounds found in essential oils, such as anethol, capsaicin, cardanol, cardol, cinnamaldehyde, eugenol and thymol, are in high concentrations in plant extracts and they can affect the cytoplasmic membrane permeability of microbes (Dorman \& Deans, 2000). Moreover, these compounds impact ruminant production by affecting protein and lipid metabolism in the rumen, stimulating of feed digestion, reduction of hyper-producing ammonia bacteria, affecting bacterial colonization of substrates in the rumen, and due to antimicrobial, anti-inflammatory and antioxidant properties (Benchaar et al., 2006; Benchaar et al., 2008; Calsamiglia et al., 2007; Chaves et al., 2008; Cruz et al., 2014; Fugita et al., 2017; Hart et al., 2008; Valero et al., 2016). For example, feeding cinnamaldehyde or essential oils from juniper berry $(200 \mathrm{mg} / \mathrm{kg}$ of DM) improved average daily gain of lambs (Chaves et al., 2008). Furthermore, synergistic effects between active coumpounds in essential oils were reported (Valero et al., 2016). Bulls fed $550 \mathrm{mg} / \mathrm{kg}$ of DM of essential oils from castor (main active compouds: ricinoleic acid) and cashew nut shell liquid (mais active compounds: anacardic acid, cardanol, and cardol) had increased body weight and lower dry matter conversion compared to a control diet (Valero et al., 2016). Nonetheless, there are few studies exploring the synergysm of essential oils in beef cattle performance and carcass characteristics. Our hypothesis was that the combination of active componds in essential oils from various plants would sinergize and improve beef cattle production and carcass characteristics. Thus, this study was performed to evaluate the effect of a mix of natural dietary essential oils on animal performance, feed efficiency and carcass characteristics of crossbred young bulls finished in feedlot and fed a high-grain diet.

\section{Material and Methods}

\subsection{Local, Animals, Diets}

This experiment was approved by the São Paulo State University "Julio de Mesquita Filho" (UNESP). This study was conducted at the Rosa \& Pedro Sector of the Experimental Station at Iguatemi Farm, Maringá, Paraná, south of Brazil.

Twenty-seven $12 \pm 2$ months-old crossbred young bulls ( $1 / 2$ Angus $v s .1 / 2$ Nellore) and their half-brothers, with an average weight of $243.5 \pm 6.8 \mathrm{~kg}$ when the trial started, were randomly assigned to one of three finishing diets (n $=9$ per treatment).

The basal diet consisted of $90 \%$ concentrate and $10 \%$ pelleted sugarcane bagasse. The diets were similar for all animals (Table 1), and were formulated according to the NRC (2000) recommendations for an average daily weight gain of $1.50 \mathrm{~kg}$. The three experimental diets were as follows: diet without the addition of the essential oil mix, or control diet (CON); diet with $500 \mathrm{mg} / \mathrm{kg}$ of DM of an essential oil mix (E500); diet with $1000 \mathrm{mg} / \mathrm{kg}$ of DM of an essential oil mix (E1000). The oil mix $\left(\mathrm{MixOil}^{\circledR}\right)$ was manufactured by Animal Wellness Products (A.W.P. ${ }^{\mathrm{TM}}$ Oakland-Nebraska-USA), and was incorporated directly into the concentrate. Components of the mix consisted of seven plant extracts: oregano (Origanum vulgare), garlic (Allium sativum), lemon (Citrus limonum), rosemary (Rosmarinus officinalis), thyme (Thymus vulgaris), eucalyptus (Eucalyptus saligna) and sweet orange (Citrus aurantium). Essential oils from oregano is enriched in carvacrol, garlic in allicin, lemon in limonene, rosemary in pinene, thyme in thymol, eucalyptus in citronellal and citronellol, and sweet orange in limonene.

Table 1. Ingredient and chemical composition and percentage of diets (\% DM)

\begin{tabular}{|c|c|c|c|c|c|c|c|c|c|c|c|}
\hline \multirow{2}{*}{ Ingredients } & \multirow{2}{*}{$\mathrm{DM}^{1}$} & \multicolumn{9}{|c|}{$\% \mathrm{DM}$} & \multirow{2}{*}{ Diet, $\%$} \\
\hline & & $\mathrm{CP}^{2}$ & $\mathrm{OM}^{3}$ & Ash & $\mathrm{EE}^{4}$ & $\mathrm{NDF}^{5}$ & $\mathrm{ADF}^{6}$ & $\mathrm{TCH}^{7}$ & $\mathrm{NFC}^{8}$ & $\mathrm{TDN}^{9}$ & \\
\hline Sugar cane bagasse & 94.70 & 1.83 & 98.02 & 1.97 & 3.60 & 78.74 & 49.20 & 89.37 & 13.86 & 42.89 & 10.00 \\
\hline Cracked corn & 88.93 & 8.99 & 99.10 & 0.95 & 3.50 & 17.70 & 4.40 & 86.60 & 68.90 & 90.00 & 81.95 \\
\hline Soybean meal & 88.60 & 49.00 & 93.70 & 6.26 & 1.30 & 13.70 & 5.97 & 43.50 & 29.80 & 84.00 & 6.51 \\
\hline Limestone & 99.30 & & 10.71 & 89.29 & & & & & & & 0.46 \\
\hline Yeast & 98.00 & 30.00 & & & & & & & & & 0.05 \\
\hline Mineral mixture $^{10}$ & 99.30 & & 10.70 & 89.30 & & & & & & & 0.41 \\
\hline Urea & 98.00 & 260.00 & 0.56 & 99.44 & & & & & & & 0.62 \\
\hline Diet & 88.13 & 12.50 & 97.34 & 2.66 & 2.20 & 30.30 & 14.80 & 84.50 & 54.20 & 70.30 & 100.00 \\
\hline
\end{tabular}

Note. ${ }^{1}$ Dry matter, ${ }^{2}$ Crude protein, ${ }^{3}$ Organic matter, ${ }^{4}$ Ether extract, ${ }^{5}$ Neutral detergent fiber, ${ }^{6}$ Acid detergent fiber, ${ }^{7}$ Total carbohydrates, ${ }^{8}$ Non-fiber carbohydrates, ${ }^{9}$ Total digestible nutrients, ${ }^{10} \mathrm{By} \mathrm{kg}$ : calcium-175 g; phosphorus-100 g; sodium-114 g; selenium-6,004 mg, magnesium-1,250 g; fluoride-1,000 mg. 


\subsection{Nutrients and Diet Analyses}

Analytical DM of feed ingredients was determined by drying at $135{ }^{\circ} \mathrm{C}$ for $3 \mathrm{~h}$ (Table 1), according to the method 930.15 (AOAC, 2005). Nitrogen content in the samples was determined by the method 976.05 (AOAC, 2005). Ash was determined through combustion at $550{ }^{\circ} \mathrm{C}$ for $5 \mathrm{~h}$ by the method 936 (AOAC, 2005). The OM content was calculated as the difference between DM and ash contents. Ether extract content was determined by the method 920.39 (AOAC, 2005). The NDF content was determined according to Mertens (2002) using $\alpha$-amylase. The ADF was determined using the method 973.18 (AOAC, 2005). The total carbohydrates were determined according to Sniffen et al. (1992) using the equation: $100-(\% \mathrm{CP}+\% \mathrm{EE}+\%$ ash). The non-fiber carbohydrate content was determined using the equation: $100-(\% \mathrm{NDF}+\% \mathrm{CP}+\% \mathrm{EE}+\%$ ashes $)$. The total digestible nutrient (TDN) content of diets was estimated using the methodology described by Kearl (1982).

\subsection{Slaughter and Carcass Measurements}

Young bulls were finished on their respective diets for 120 days until they reached commercial weights $(440.3 \pm 10.0 \mathrm{~kg}$ ). Bulls were slaughtered at a commercial abattoir $60 \mathrm{~km}$ from the feedlot after a fast of solids (14 hours), according Brazilian slaughter practices. The bulls were stunned using a captive-bolt pistol. Animals were bled through exsanguination by cutting the neck vessels, and the head, hide, viscera, tail, legs, diaphragm and excess internal fat was removed. The carcasses were divided medially from the sternum and spine, resulting in two similar halves, which were weighed to calculate the hot carcass weight (HCW). Next, the half-carcasses were identified and stored in a chilling chamber at $4{ }^{\circ} \mathrm{C}$ for 24 -h period.

The following carcass traits were obtained: HCW was determined after the slaughter and before the carcass was chilled; the percentage of the individual animal dressing was defined as the HCW divided by the live weight 14 hours before slaughter; cold carcass weight was determined after chilling the carcass at $4{ }^{\circ} \mathrm{C}$ for 24 -h period; cold carcass dressing was defined as the cold carcass weight divided by the live weight 14 hours before slaughter; carcass length was determined by measuring the carcass from the border of the pubis bone until the anterior side of the first rib taken with a ribbon or a tape line; leg length was evaluated using a wooden compass with metallic edges that measures the distance from the anterior border of the pubis bone to a middle point on the tarsus bone; cushion thickness was determined using a wooden compass with metallic edges that measures the distance between the lateral face to the median at the superior part of the cushion (Biceps femoris); fat thickness was determined with a caliper averaging three points between the $12^{\text {th }}$ and the $13^{\text {th }}$ ribs on the Longissimus muscle (LM); LM area was measured using a compensating planimeter on a transversal cut between the $12^{\text {th }}$ and $13^{\text {th }}$ ribs; carcass muscle, fat and bone were physically separated from the Longissimus section, which corresponds to the $6^{\text {th }}$ rib, and individually weighed according to Robelin and Geay (1975).

\subsection{Statistical Analysis}

The experimental design was completely randomized, with three treatments and nine replications. All studied characteristics were tested for normality (Shapiro-Wilk test). Characteristics that presented normal distribution were analyzed using an analysis of variance using the procedure proc MIXED of SAS (2004) statistical package (Statistical Analysis System, version 8.1). The model statement contained the fixed effect of the diet. Data were analyzed using bull as random variable. Results are reported as least square means and discriminated using PDIFF. Differences between group means were assessed by using the Tukey Test $(\mathrm{P}<0.05)$.

\section{Results and Discussion}

\subsection{Animal Performance and Feed Efficiency}

There is limited information on the effects of the supplementation of a mix of essential oils for beef cattle finished in feedlot on feed intake, animal performance and carcass characteristics. Additionally, the results from the existing studies are conflicting. In this study, the addition of 500 or $1000 \mathrm{mg} / \mathrm{kg}$ of DM of a mix of essential oils from oregano, garlic, lemon, rosemary, thyme, eucalyptus and sweet orange (main active compounds: carvacrol, allicin, limonene, pinene, thymol, citronellal and citronellol) in the diet of crossbred bulls did not affect $(\mathrm{P}>0.05)$ the final body weight $(\mathrm{FBW})$ and average daily gain $(\mathrm{ADG})$ of bulls finished in feedlot (Table 2). Benchaar et al. (2006) fed crossbred steers and heifers (Angus vs. Hereford) with distinct levels ( 250 or 500 $\mathrm{mg} / \mathrm{kg}$ of DM) of a mix of essential oils (clove, vanillin, lemon and thymus), and no differences in FBW and ADG were observed. Likewise, no differences on FBW and ADG were observed when young steers received 80 $\mathrm{mg} / \mathrm{kg}$ of DM of a mix of thymol, eugenol, vanillin, guaiacol and limonene (Meyer et al., 2009). On the other hand, Valero et al. (2016) observed improved ADG (1.55 vs. $1.26 \mathrm{~kg} / \mathrm{d})$ when bulls finished in feedlot were supplemented with $550 \mathrm{mg} / \mathrm{kg}$ of DM of cashew and castor oil (main active compounds: ricinoleic acid, anacardic, cardol and cardanol). Also, lambs fed $200 \mathrm{mg} / \mathrm{kg}$ of DM of cinnamaldehyde or juniper berry essential 
oil (main active compound: $\alpha$-pinene) had improved ADG (Chaves et al., 2008). In a trial using supplementation of increasing doses of cinnamaldehyde as single active compound (400, 800, and $1600 \mathrm{mg} / \mathrm{animal} / \mathrm{d})$, Yang et al. (2009) observed no differences in FBW and ADG for steers finished in feedlot. Thus, other variables than the quantities of the essential oil supplemented also impact responses of FBW and ADG on animal studies. For example, various active compounds such as carvacrol, allicin, thymol, limonene and pinene, have a broad antibacterial activity, with potential to affect Gram-positive and Gram-negative bacteria (Benchaar \& Greathead, 2011). Thus, essential oils can modulate the rumen microbiota, consequently affecting the production volatile organic compounds and protein degradation (Calsamiglia et al., 2007). Also, essential oils can result in decreased total volatile fatty acid production (Cardozo et al., 2005).

The average FBW and ADG was $440.3 \pm 10.0$ and $1.64 \pm 0.04 \mathrm{~kg}$, respectively. In general, crossbred young bulls (Bos taurus vs. Bos indicus) finished in feedlot are slaughtered with 470 to $500 \mathrm{~kg}$ of body weight in Brazil (Ito et al., 2012) and with an ADG between 1.4 and $1.8 \mathrm{~kg}$ (Rotta et al., 2009). The high ADG observed in this study (average of $1.64 \mathrm{~kg}$ ) might be explained due to the use of young bulls slaughtered at 16 months-old. Young animals have hormones that promotes increased growth compared to old animals (Henricks, 1991). Also, young bulls have high levels of testosterone compared to steers, which maintain and promote male secondary sexual characteristics and muscle development (Prado et al., 2009; Marti et al., 2017). Moreover, crossbred cattle (e.g. Bos taurus vs. Bos indicus) have high ADG due to heterosis expression in the first generation (Ito et al., 2012; Prado et al., 2009; Rotta et al., 2009).

The addition of essential oils in the diets did not alter $(\mathrm{P}>0.05)$ dry matter intake (DMI). The DMI was 7.1 $\mathrm{kg}$ /day and DMI ratio to body weight was $2.1 \%$. Low DMI ratio to BW can be explained by a diet with high concentrate $(90 \%)$, which have a greater energetic density compared to roughages. The effect of essential oils and DMI is also conflicting. Benchaar et al. (2006) observed similar DMI on a growth-performance trial, but observed increased DMI on a digestibility trial, both using beef cattle fed similar diets with supplementation of essential oils ( $\sim 250$ or $500 \mathrm{mg} / \mathrm{kg}$ of DM) from clove, vanillin, lemon and thymus. Yang et al. (2009) observed a positive short-term effect on DMI (from day 1 to 28) when crossbred steers finished in feedlot (Hereford vs. Angus) were fed increasing doses of cinnamaldehyde (400, 800 and $1600 \mathrm{mg} / \mathrm{d})$. On the other hand, feeding $\sim 500 \mathrm{mg} / \mathrm{kg}$ of DM of castor bean and cashew essential oils had no effect on DMI of crossbred bulls (Angus vs. Nellore) finished in feedlot (Fugita et al., 2017). Also, Chaves et al. (2008) did not observed effect on DMI when lambs were fed $200 \mathrm{mg} / \mathrm{kg}$ of DM of cinnamaldehyde or juniper berry essential oil. Furthermore, Cardozo et al. (2006) supplemented Holstein heifers with cinnamaldehyde (25 mg/kg of DM) combined to eugenol (12 mg/kg of DM) and observed decreased in DMI. Some essential oils or active compounds in plant extracts can improve, be neutral, or decrease palatability from diets (Calsamiglia et al., 2007; Yang et al., 2009). Thus, palatability or encapsulation of the essential oil need to be considered prior to supplementation.

Table 2. Animal performance, feed intake and feed efficiency of crossbred young bulls ( $1 / 2$ Angus $v s .1 / 2$ Nellore) finished in feedlot supplemented with a mix of essential oils

\begin{tabular}{|c|c|c|c|c|c|c|}
\hline \multirow{2}{*}{ Parameters } & \multicolumn{3}{|c|}{ Diets } & \multirow{2}{*}{ Mean } & \multirow{2}{*}{$\mathrm{SEM}^{4}$} & \multirow{2}{*}{$\mathrm{P}<\mathrm{F}$} \\
\hline & $\mathrm{CON}^{1}$ & $\mathrm{E} 500^{2}$ & $\mathrm{E} 1000^{3}$ & & & \\
\hline Initial body weight, $\mathrm{kg}$ & 244.4 & 245.2 & 240.9 & 243.5 & 6.79 & 0.94 \\
\hline Final body weight, $\mathrm{kg}$ & 444.8 & 431.2 & 444.9 & 440.3 & 10.03 & 0.82 \\
\hline Average daily gain, $\mathrm{kg}$ & 1.67 & 1.55 & 1.70 & 1.64 & 0.04 & 0.37 \\
\hline Dry matter intake, $\mathrm{kg} / \mathrm{d}$ & 7.08 & 7.08 & 7.05 & 7.07 & 0.21 & 0.99 \\
\hline Dry matter intake, \%/BW & 2.05 & 2.09 & 2.06 & 2.07 & 0.04 & 0.95 \\
\hline Dry matter conversion & 4.24 & 4.56 & 4.14 & 4.31 & 0.08 & 0.08 \\
\hline Crude protein intake, $\mathrm{kg} / \mathrm{d}$ & 0.88 & 0.88 & 0.86 & 0.87 & 0.02 & 0.99 \\
\hline Neutral detergent intake, $\mathrm{kg} / \mathrm{d}$ & 1.49 & 1.48 & 1.48 & 1.48 & 0.04 & 0.99 \\
\hline Neutral detergent intake, \%/BW & 0.43 & 0.44 & 0.43 & 0.43 & 0.08 & 0.96 \\
\hline
\end{tabular}

Note. ${ }^{1}$ CON: basal diet without essential oils, ${ }^{2}$ E500: basal diet with addition of $500 \mathrm{mg} / \mathrm{kg}$ of DM/animal/day of a mix of essential oils, ${ }^{3} \mathrm{E} 1000$ : basal diet with addition of $1000 \mathrm{mg} / \mathrm{kg}$ of DM/animal/day of a mix of essential oils, ${ }^{4}$ Standard mean error.

There was a tendency $(\mathrm{P}<0.08)$ for improved feed efficiency with addition of $500 \mathrm{mg} / \mathrm{kg}$ of DM of a mix of essential oils in the diet when compared to a basal diet (Table 2). Benchaar et al. (2006) observed improved feed 
efficiency for beef cattle supplemented with the inclusion of $\sim 250 \mathrm{mg} / \mathrm{kg}$ of DM of essential oils. Likewise, Valero et al. (2016) observed improved feed efficiency for bulls finished in feedlot and supplemented with 550 $\mathrm{mg} / \mathrm{kg}$ of DM of essential oils (cashew and castor). On the other hand, Fugita et al. (2017) did not observe difference on feed efficiency with the addition of $\sim 500 \mathrm{mg} / \mathrm{kg}$ of DM of cashew and castor oil in the diet of bulls finished in feedlot. Essential oils can affect methanogens and decrease methane production, thus improving energy efficiency in the rumen (Benchaar \& Greathead, 2011). Also, some active compounds in essential oils, such as carvacrol, can increase the production of propionate in the rumen, which is a precursor of glucose in ruminants (Chaves et al., 2008).

The NDF intake ratio to body weight was low $(0.43 \%)$. Thus, there was no DMI limitation due to physical rumen fill. Mertens (1994) observed that NDF intake of $1.2 \%$ of BW or lower would not be a limiting factor for the intake of nutrients. The feed conversion was approximately $4.3 \mathrm{~kg}$ of DM for $1 \mathrm{~kg}$ of BW gain and may be attributed to the genetic quality of animals ( $1 / 2$ Angus vs. $1 / 2$ Angus), their sexual condition (bulls) and the high-energy density of the diet $(70 \% \mathrm{TDN})$. Usually, crossbred bulls fed on a high-energy density diets have decreased DMI and feed conversion of 5-6 kg of DM intake for $1 \mathrm{~kg}$ of BW gain (Valero et al., 2016; Fugita et al., 2017), resulting in improved feed efficiency (NRC, 2000).

\subsection{Carcass Characteristics}

There is limited information on the effect of essential oils on beef cattle carcass traits. The addition of essential oils in the diets of crossbred bulls finished in feedlot did not affect $(\mathrm{P}>0.05)$ carcass weight (hot and cold), carcass dressing (hot and cold), carcass length, leg length or cushion thickness (Table 3). Mean carcass weight, carcass dressing, carcass length, leg length and cushion thickness were $243 \mathrm{~kg}, 55 \%, 124 \mathrm{~cm}, 79 \mathrm{~cm}$ and $25.0 \mathrm{~cm}$, respectively. Thus, carcass weight, dressing and conformation and cushion thickness were close to the rates reported for crossbred Bos taurus taurus vs. Bos taurus indicus finished in feedlot and fed on a high-energy density diet (Prado et al., 2008; Rotta et al., 2009).

Table 3. Carcass characteristics of crossbred young bulls ( $1 / 2$ Angus vs. $1 / 2$ Nellore) finished in feedlot supplemented with a mix of essential oils

\begin{tabular}{|c|c|c|c|c|c|c|}
\hline \multirow{2}{*}{ Parameters } & \multicolumn{3}{|c|}{ Diets } & \multirow{2}{*}{ Mean } & \multirow{2}{*}{$\mathrm{SEM}^{4}$} & \multirow{2}{*}{$\mathrm{P}<\mathrm{F}$} \\
\hline & $\mathrm{CON}^{1}$ & $\mathrm{E} 500^{2}$ & $\mathrm{E} 1000^{3}$ & & & \\
\hline Hot carcass weight, kg & 243.16 & 239.76 & 245.68 & 242.86 & 6.35 & 0.93 \\
\hline Hot carcass dressing, $\%$ & 54.60 & 55.48 & 55.14 & 55.07 & 0.34 & 0.58 \\
\hline Cold carcass weight, $\mathrm{kg}$ & 238.40 & 235.06 & 240.86 & 238.11 & 6.22 & 0.93 \\
\hline Cold carcass dressing, $\%$ & 53.53 & 54.40 & 54.06 & 54.00 & 0.33 & 0.58 \\
\hline Carcass length, $\mathrm{cm}$ & 123.16 & 124.27 & 123.66 & 123.70 & 0.78 & 0.85 \\
\hline Leg length, $\mathrm{cm}$ & 79.94 & 78.88 & 78.72 & 79.18 & 0.97 & 0.86 \\
\hline Cushion thickness, $\mathrm{cm}$ & 24.72 & 25.00 & 25.44 & 25.05 & 0.39 & 0.76 \\
\hline Fat thickness, mm & 6.66 & 6.98 & 6.39 & 6.68 & 0.40 & 0.84 \\
\hline Muscle area, $\mathrm{cm}^{2}$ & 71.11 & 71.66 & 74.22 & 72.33 & 1.77 & 0.76 \\
\hline Ratio $^{5}, \mathrm{~cm}^{2}$ & 0.51 & 0.52 & 0.54 & 0.52 & 0.01 & 0.54 \\
\hline Muscle, $\%$ & 59.89 & 58.89 & 62.18 & 60.32 & 0.69 & 0.14 \\
\hline Fat, \% & 18.08 & 17.98 & 16.38 & 17.48 & 0.80 & 0.64 \\
\hline Bone, $\%$ & 15.10 & 16.04 & 15.67 & 15.60 & 0.52 & 0.77 \\
\hline
\end{tabular}

Note. ${ }^{1}$ CON: basal diet without essential oils, ${ }^{2}$ E500: basal diet with addition of $500 \mathrm{mg} / \mathrm{kg}$ of DM/animal/day of a mix of essential oils, ${ }^{3} \mathrm{E} 1000$ : basal diet with addition of $1000 \mathrm{mg} / \mathrm{kg}$ of DM/animal/day of a mix of essential oils, ${ }^{4}$ Standard mean error, ${ }^{5}$ Ratio between muscle length and muscle width.

Fat thickness, muscle area and ratio were similar $(\mathrm{P}>0.05)$ between diets (Table 3). Mean fat thickness was 6.7 $\mathrm{mm}$, muscle area was $72.3 \mathrm{~cm}^{2}$ and the ratio was $0.52 \mathrm{~cm}^{2}$, respectively. The fat thickness was high for the requirements of the Brazilian market. In general, fat thickness ranges between 3 to $6 \mathrm{~mm}$ (Rotta et al., 2009). The muscle area ranges from 68 to $75 \mathrm{~cm}^{2}$ and ratio from 0.50 to $56 \mathrm{~cm}^{2}$. Despite having FBW lower than 470 $\mathrm{kg}$, carcasses presented good fat thickness and conformation.

Essential oil addition in the diets had no effect $(\mathrm{P}>0.05)$ on muscle, fat and bone percentage in the carcass of bulls finished in feedlot (Table 3). The mean percentage of muscle on LM was $60.3 \%$, fat $17.5 \%$ and bone 
15.6\%. Similarly, some authors reported muscle percentages between 58 and $62 \%$, fat between 15 and $20 \%$ and bone between 15 and 18\% on LM of crossbred bulls (Ito et al., 2012; Prado et al., 2008; Rotta et al., 2009).

In general, the addition of essential oils in the diet of cattle finished in feedlot and fed on a diet with high energy density has no effect in carcass traits (Benchaar et al., 2006; Cruz et al., 2014; Fugita et al., 2017). This is consistent with other studies using beef cattle and lambs (Chaves et al., 2008; Cruz et al., 2014; Yang et al., 2009). Lack of effects of essential oils on carcass traits is in agreement with the absence of the effects of essential oils on ADG and feed efficiency in the present study. Nonetheless, essential oils fed to beef cattle can result in meat with increased shelf life and antioxidants concentration (Monteschio et al., 2017; Rivaroli et al., 2016). Moreover, acceptability of meat from young bulls was improved with the inclusion of a mix of essential oils in the diet (Guerrero et al., 2017).

\section{Conclusion}

The addition of a mix of essential oils (500 or $1000 \mathrm{mg} / \mathrm{kg}$ of DM - oregano (Origanum vulgare), garlic (Allium sativum), lemon (Citrus limonium), rosemary (Rosmarinus officinalis), thymol (Thymus vulgaris), eucalyptus (Eucalyptus saligna) and sweet orange (Citrus aurantium) in the diets of crossbred bulls finished in feedlot fed high-concentrate diet did not affect animal performance and carcass characteristics, but there was a tendency for improved feed efficiency when $500 \mathrm{mg} / \mathrm{kg}$ of DM of the mix was added. More studies are needed to elucidate the synergism of mixtures of essential oils in the rumen, and how it affects the rumen microbiome.

\section{References}

AOAC. (2005). Official methods of analysis of AOAC International (18th ed.). Maryland, MD: Association of Official Analytical Chemists.

Benchaar, C., \& Greathead, H. (2011). Essential oils and opportunities to mitigate enteric methane emissions from ruminants. Animal Feed Science and Technology, 166-167, 338-355. https://doi.org/10.1016/ j.anifeedsci.2011.04.024

Benchaar, C., Calsamiglia, S., Chaves, A. V., Fraser, G. R., Colombatto, D., McAllister, T. A., \& Beauchemin, K. A. (2008). A review of plant-derived essential oils in ruminant nutrition and production. Animal Feed Science and Technology, 145(1-4), 209-228. https://doi.org/10.1016/j.anifeedsci.2007.04.014

Benchaar, C., Duynisveld, J. L., \& Charmley, E. (2006). Effects of monensin and increasing dose levels of a mixture of essential oil compounds on intake, digestion and growth performance of beef cattle. Canadian Journal of Animal Science, 86(1), 91-96. https://doi.org/10.4141/A05-027

Burt, S. (2004). Essential oils: their antibacterial properties and potential applications in foods-A review. International Journal of Food Microbiology, 94(3), 223-253. https://doi.org/10.1016/j.ijfoodmicro.2004. 03.022

Calsamiglia, C., Busquet, M., Cardozo, P. W., Castillejos, L., \& Ferret, A. (2007). Essential oils as modifiers of rumen microbial fermentation. Journal of Dairy Science, 90(6), 2580-2595. https://doi.org/10.3168/ jds.2006-644

Cardozo, P. W., Calsamiglia, S., Ferret, A., \& Kamel, C. (2005). Screening for the effects of natural plant extracts at different $\mathrm{pH}$ on in vitro rumen microbial fermentation of a high-concentrate diet for beef cattle. Journal of Animal Science, 83, 2572-2579. https://doi.org/10.2527/2005.83112572x

Cardozo, P. W.,Calsamiglia, S., Ferret, A., \& Kamel, C. (2006). Effects of alfalfa extract, anise, capsicum and a mixture of cinnamaldehyde and eugenol on ruminal fermentation and protein degradation in beef heifers fed a high concentrate diet. Journal of Animal Science, 84, 2801-2808. https://doi.org/10.2527/jas.2005-593

Chaves, A. V., Stanford, K., Gibson, L., McAllister, T. A., \& Benchaar, C. (2008). Effects of cinnamaldehyde, garlic and juniper berry essential oils on rumen fermentation, blood metabolites, growth performance, and carcass characteristics of growing lambs. Livestock Science, 117(2-3), 215-224. https://doi.org/10.1016/ j.livsci.2007.12.013

Cruz, O. T. B., Valero, M. V., Zawadzki, F., Rivaroli, D. C., Prado, R. M., Lima, B. S., \& Prado, I. N. (2014). Effect of glycerine and essential oils (Anacardium occidentale and Ricinus communis) on animal performance, feed efficiency and carcass characteristics of crossbred bulls finished in a feedlot system. Italian Journal of Animal Science, 13(4), 3492. https://doi.org/10.4081/ijas.2014.3492 
Dorman, H. J. D., \& Deans, S. G. (2000). Antimicrobial agents from plants: Antibacterial activity of plant volatile oils. Journal of Applied Microbiology, 88(2), 308-316. https://doi.org/10.1046/j.1365-2672.2000. 00969.x

Ferraz, J. B. S, \& Felício, P. E. (2010). Production systems-An example from Brazil. Meat Science, 84, 238-243. https://doi.org/10.1016/j.meatsci.2009.06.006

Fugita, C. A., Prado, R. M., Valero, M. V., Bonafé, E. G., Carvalho, C. B., Guerrero, A., ... Prado, I. N. (2017). Effect of the inclusion of natural additives on animal performance and meat quality of crossbred bulls (Angus $\times$ Nellore) finished in feedlot. Animal Production Science. https://doi.org/10.1071/AN16242

Greathead, H. (2003). Plants and plant extracts for improving animal productivity. Proceedings of the Nutrition Society, 62(2), 279-290. https://doi.org/10.1079/PNS2002197

Guerrero, A., Rivaroli, D. C., Sañudo, C., Campo, M. M., Valero, M. V., Jorge, A. M., \& Prado, I. N. (2017). Consumer acceptability of beef from two sexes supplemented with essential oil mix. Animal Production Science. https://doi.org/10.1071/AN15306

Hart, K. J., Yáñez-Ruiz, D. R., Duval, S. M., McEwan, N. R., \& Newbold, C. J. (2008). Plant extracts to manipulate rumen fermentation. Animal Feed Science and Technology, 147, 8-35. https://doi.org/10.1016/ j.anifeedsci.2007.09.007

Henricks, D. M. (1991). Biochemistry and physiology of the gonadal hormones. In P. T. Cupps (Ed.), Reproduction in Domestic Animals (Vol. 1, pp. 81-118). San Diego: Academic Press, Inc. https://doi.org/10.1016/B978-0-08-057109-6.50008-2

Ito, R. H., Prado, I. N., Rotta, P. P., Oliveira, M. G., Prado, R. M., \& Moletta, J. L. (2012). Carcass characteristics, chemical composition and fatty acid profile of Longissimus muscle of young bulls from four genetic groups finished in feedlot. Revista Brasileira de Zootecnia, 41(2), 384-391. https://doi.org/10.1590/ S1516-35982012000200022

Kearl, L. C. (1982). Nutrient Requirements of Ruminants in Developing Countries (1st ed.). Utah, UT, USA: International Feedstuffs Institute, Utah Agricultural Experiment Station, Utah State University.

Marti, S., Jackson, J. A., Slootmans, N., Lopez, E., Hodge, A., Pérez-Juan, M., ... Amatayakul-Chantler, S. (2017). Effects on performance and meat quality of Holstein bulls fed high concentrate diets without implants following immunological castration. Meat Science, 126, 36-42. https://doi.org/10.1016/j.meatsci. 2016.11.013

Mertens, D. R. (1994). Regulation of forage intake. In J. R. Fahey (Ed.), Forage Quality, Evaluation, and Utilization (pp. 450-493). Madison, WI, USA: American Society of Agronomy.

Mertens, D. R. (2002). Gravimetric determination of amylase-treated neutral detergent fiber in feeds with refluxing in beakers or crucibles: Collaborative study. Journal of AOAC International, 85(6), 1217-1240.

Meyer, N. F., Erickson, G. E., Klopfenstein, T. J., Greenquist, M. A., Luebbe, M. K., Williams, P., \& Engstrom, M. A. (2009). Effect of essential oils, tylosin, and monensin on finishing steer performance, carcass characteristics, liver abscesses, ruminal fermentation, and digestibility. Journal of Animal Science, 87, 2346-2354. https://dx.doi.org 10.2527/jas.2008-1493

Monteschio, J. O., Souza, K. A., Vital, A. C. P., Guerrero, A., Valero, M. V., Kempinski, E. M. B. C., \& Prado, I. N. (2017). Clove and rosemary essential oils and encapsuled active principles (eugenol, thymol and vanillin blend) on meat quality of feedlot-finished heifers. Meat Science, 130, 50-57. https://doi.org/10.1016/ j.meatsci.2017.04.002

NRC. (2000). Nutrient Requirements of Beef Cattle (7th rev. ed.). Washington, DC, USA: Natl. Acad. Press.

OJEU. (2003). Regulation (EC) No 1831/2003 of the European Parliament and the Council of 22 September 2003 on additives for use in animal nutrition. Official Journal of the European Union, 268-236.

Owens, F. N., Secrist, D. S., Hill, W. J., \& Gill, D. R. (1998). Acidosis in cattle: A review. Journal of Animal Science, 76(1), 275-286. https://doi.org/10.2527/1998.761275x

Prado, I. N., Prado, R. M., Rotta, P. P., Visentainer, J. V., Moletta, J. L., \& Perotto, D. (2008). Carcass characteristics and chemical composition of the Longissimus muscle of crossbred bulls (Bos taurus indicus vs. Bos taurus taurus) finished in feedlot. Journal of Animal and Feed Sciences, 17, 295-306. https://doi.org/10.22358/jafs/66609/2008 
Prado, R. M., Prado, I. N., Marques, J. A., Rotta, P. P., Prado, R. M., Visentainer, J. V., \& Souza, N. E. (2009). Meat quality of the Longissimus muscle of bulls and steers ( $1 / 2$ Nellore $v s .1 / 2$ Simmental) finished in feedlot. Journal of Animal and Feed Sciences, 18, 221-230. https://doi.org/10.22358/jafs/66386/2009

Rivaroli, D. C., Guerrero, A., Valero, M. M., Zawadzki, F., Eiras, C. E., Campo, M. M., \& Prado, I. N. (2016). Effect of essential oils on meat and fat qualities of crossbred young bulls finished in feedlots. Meat Science, 121, 278-284. https://doi.org/10.1016/j.meatsci.2016.06.017

Robelin, J., \& Geay, Y. (1975). Estimation de la composition de la carcasse des taurillons a partir de la 6ème côte. Bulletin Technique. Centre de Recherches Zootechniques et Veterinaires de Theix, 22(1), 41-44.

Rotta, P. P., Prado, R. M., Prado, I. N., Valero, M. V., Visentainer, J. V., \& Silva, R. R. (2009). The effects of genetic groups, nutrition, finishing systems and gender of Brazilian cattle on carcass characteristics and beef composition and appearance: a review. Asian-Australasian Journal of Animal Sciences, 22(12), 1718-1734. https://doi.org/10.5713/ajas.2009.90071

Russell, J. B., \& Houlihan, A. J. (2003). Ionophore resistance of ruminal bacteria and its potential impact on human health. FEMS Microbiology Reviews, 27(1), 65-74. https://doi.org/10.1016/S0168-6445(03)00019-6

Russell, J. B., \& Strobel, H. J. (1989). Effect of ionophores on ruminal fermentation. Applied and Environmental Microbiology, 55(1), 1-6.

SAS. (2004). SAS/STAT User guide, Version 9.1.2. Cary, NC, USA: SAS Institute Inc.

Sniffen, C. J., O’Connor, J. D., Van Soest, P. J., Fox, D. G., \& Russell, J. B. (1992). A net carbohydrate and protein system for evaluating cattle diets: II. Carbohydrate and protein availability. Journal of Animal Science, 70(11), 3562-3577. https://doi.org/10.2527/1992.70113562x

Valero, M. V., Farias, M. S., Zawadzki, F., Prado, R. M., Fugita, C. A., Rivaroli, D. C., \& Prado, I. N. (2016). Feeding propolis or functional oils (cashew and castor oils) to bulls: performance, digestibility and blood cells counts. Revista Colombiana de Ciencias Pecuarias, 29, 33-42. https://doi.org/10.17533/udea.rccp. v29n1a04

Yang, W. Z., Ametaj, B. N., Benchaar, C., He, M. L., \& Beauchemin, K. A. (2009). Cinnamaldehyde in feedlot cattle diets: Intake, growth performance, carcass characteristics, and blood metabolites. Journal of Animal Science, 88, 1082-1092. https://doi.org/10.2527/jas.2008-1608

\section{Copyrights}

Copyright for this article is retained by the author(s), with first publication rights granted to the journal.

This is an open-access article distributed under the terms and conditions of the Creative Commons Attribution license (http://creativecommons.org/licenses/by/4.0/). 